\title{
ISOLATION OF CYTOTOXIC NEOLIGNANS FROM Saururus cernuus L. (SAURURACEAE) USING IONIC LIQUID IN THE MICROWAVE ASSISTED EXTRACTION (MAE)
}

\author{
Juliana R. Brito ${ }^{a}$, Fernanda F. Camilo ${ }^{a}$, Carlos R. Figueiredo ${ }^{b}$, Ricardo A. Azevedo ${ }^{\mathrm{b}}$, Paulete Romoff , Fátima O. S. Buturi $^{\mathrm{d}}$, \\ Oriana A. Fávero ${ }^{\mathrm{e}}$, João Henrique G. Lago ${ }^{\mathrm{f}, *}$ and Edgard A. Ferreira ${ }^{\mathrm{c}, \#}$ \\ Instituto de Ciências Ambientais, Químicas e Farmacêuticas, Universidade Federal de São Paulo, 09972-270 Diadema - SP, Brasil

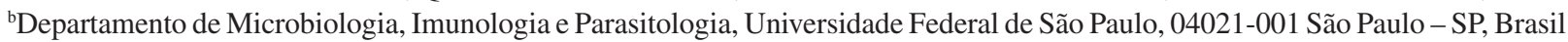 \\ ${ }^{\circ}$ Escola de Engenharia, Universidade Presbiteriana Mackenzie, 01302-907 São Paulo - SP, Brasil \\ ${ }^{d}$ Faculdade de Ciências Biológicas e da Saúde, Universidade São Judas Tadeu, 03166-000 São Paulo - SP, Brasil

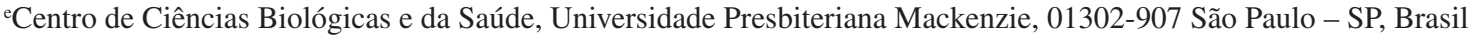 \\ ${ }_{\mathrm{f}}$ Centro de Ciências Naturais e Humanas, Universidade Federal do ABC, 09210-580 Santo André - SP, Brasil
}

Recebido em 24/04/2018; aceito em 10/05/2018; publicado na web em 19/06/2018

\begin{abstract}
In the present work, dried leaves of Saururus cernuus (Saururaceae) were subjected to extraction using an ionic liquid (1-butyl-3methylimidazolium bromide - BMImBr) in the microwave assisted extraction (MAE). The obtained extract was partitioned using $n$-hexane and cytotoxicity activity of this organic phase against murine melanoma cell line (B16F10-Nex2) was evaluated in vitro. Since this extract displayed activity ( $100 \%$ of cell death at $\left.200 \mu \mathrm{g} \mathrm{mL} \mathrm{m}^{-1}\right)$ it was subjected to a bioactivity-guided fractionation to afford four related neolignans: threo-austrobailignan-5 (1), threo-austrobailignan-6 (2), threo-dihydroguaiaretic acid (3) and saucernetin (4). Their chemical structures were established based on NMR and MS spectral analysis. Among the isolated neolignans, compound 2 exhibited the highest cytotoxic activity against $\mathrm{HeLa}$ (human cervical melanoma) cells with $\mathrm{IC}_{50}$ of $28.3 \pm 3.9 \mu \mathrm{g} \mathrm{mL}$ $\left(86 \pm 12 \mu \mathrm{mol} \mathrm{L}{ }^{-1}\right)$. Furthermore, compounds $\mathbf{2}$ and $\mathbf{3}$ exhibited the highest cytotoxic activity against A2058 (human melanoma) cells with $\mathrm{IC}_{50}$ of $44.3 \pm 4.2 \mu \mathrm{g} \mathrm{mL}^{-1}\left(135 \pm 13 \mu \mathrm{mol} \mathrm{L}^{-1}\right)$ and $41.5 \pm 7.5 \mu \mathrm{g} \mathrm{mL}^{-1}\left(126 \pm 23 \mu \mathrm{mol} \mathrm{L}^{-1}\right)$, respectively, similar to positive control cisplatin $\left(\mathrm{IC}_{50}=43.2 \pm 3.2 \mu \mathrm{g} \mathrm{mL}-1\right.$ or $\left.144 \pm 11 \mu \mathrm{mol} \mathrm{L}^{-1}\right)$. Otherwise, compound 4 was inactive $\left(\mathrm{IC}_{50}>100 \mu \mathrm{g} \mathrm{mL} \mathrm{mor}^{-1}\right.$ $>300 \mu \mathrm{mol} \mathrm{L} \mathrm{L}^{-1}$ ). The obtained results provide important data for the selection of bioactive neolignans with promising cytotoxic potential using a simple and fast method employing a green solvent as 1-butyl-3-methylimidazolium bromide (BMImBr).
\end{abstract}

Keywords: Saururaceae, Saururus cernuus, neolignans, cytotoxic activity, ionic liquids.

\section{INTRODUCTION}

Saururaceae is formed by four genera and six species of herbaceous plants distributed in Asia and North America. ${ }^{1}$ The genus Saururus is composed exclusively of two species - S. cernuus and S. chinensis which are chemically composed by flavonoids, alkaloids, terpenoids, steroids and mainly several subclasses of lignans/neolignans including tetrahydrofuran, dibenzylbutane and dibenzocyclooctene derivatives. ${ }^{2-10}$ Among these lignoids, several compounds have showed biological properties such as anti-inflammatory, ${ }^{11}$ antitumor, ${ }^{12}$ antiviral,,${ }^{9}$ and hepatoprotective effects. ${ }^{13}$ S. cernuus, popularly known as lizard's tail, is distributed in Southeastern of United States ${ }^{14}$ and it is found in Brazil as an exotic species and it has been used in folk medicine for the treatment of inflammation, fever, edema and antitumor. ${ }^{14-16}$ Previous studies reported the tumor specific cytotoxicity of manassantins A and $\mathrm{B}$ as well as 4-O-demethylmanassantin B. ${ }^{16-19}$

The extraction procedures of bioactive compounds from natural sources frequently employed toxic organic solvents in large amounts, leading to a significant environmental impact. ${ }^{20}$ Based in this aspect our research group developed a simple and efficient method of extraction using ionic liquids in aqueous solvent assisted by microwave. ${ }^{21}$ In continuation with these studies, the leaves of S. cernuus were subjected to extraction using aqueous 1-butyl-3methylimidazolium bromide (BMImBr) under microwave assisted extraction (MAE) and the obtained material was extracted with $n$-hexane. As this organic phase displayed in vitro activity against

*e-mail: joao.lago@ufabc.edu.br

\#alternative e-mail: edgard.ferreira@mackenzie.br tumorigenic cell lines of murine melanoma (B16F10) cells it was subjected to a bioactivity-guided fractionation to afford the isolation of threo-austrobailignan-5 (1), threo-austrobailignan-6 (2) and threodihydroguaiaretic acid (3) as well as an inactive related compound saucernetin (4).

\section{RESULTS AND DISCUSSION}

After extraction of dried leaves from $S$. cernuus using aqueous 1-butyl-3-methylimidazolium bromide (BMImBr) under MAE during $10 \mathrm{~min}$ at $60^{\circ} \mathrm{C}$, the obtained material was filtered and extracted using $n$-hexane. This organic phase displayed cytotoxic effects against B16F10 (murine melanoma) tumor cell line $(100 \%$ of cell death at $200 \mu \mathrm{g} \mathrm{mL} \mathrm{m}^{-1}$ ) and was subjected to a bioactivityguided chromatographic fractionation to afford four related known neolignans: threo-austrobailignan-5 (1), threo-austrobailignan-6 (2), threo-dihydroguaiaretic acid (3) and saucernetin (4), as showed in Figure 1.

Identification of bioactive isolated compounds was carried out by analysis of their spectral data, especially NMR and MS. Compounds 1-3 were characterized as dibenzylbutane neolignans by analysis of their ${ }^{1} \mathrm{H}$ NMR spectra, in which were observed typical signals of a 1,2,4-trissubstituted aromatic ring at $\delta$ 6.51-6.61 (d, $J=1.5 \mathrm{~Hz}, \mathrm{H}-2), 6.68-6.81(\mathrm{~d}, J=7.8 \mathrm{~Hz}, \mathrm{H}-5)$ and $\delta 6.50-6.58$ (dd, $J=7.8$ and $1.5 \mathrm{~Hz}, \mathrm{H}-6$ ), two peaks assigned to diasteriotopic benzylic hydrogens (H-7) at approximately $\delta 2.5(\mathrm{dd}, J=13.5$ and $6.6 \mathrm{~Hz}$ ) and $2.3(\mathrm{dd}, J=13.5$ and $8.1 \mathrm{~Hz}$ ), one signal attributed to methyl group $(\mathrm{H}-9)$ at $\delta 0.79-0.82(\mathrm{~d}, J=6.6 \mathrm{~Hz})$ and one multiplet at $\delta 1.72-1.75$ assigned to $\mathrm{H}-8$. The ${ }^{1} \mathrm{H}$ NMR spectrum 
<smiles>[R]c1ccc([C]([Te])[C@H](C)[C@H](C)c2ccc([R])c([R3])c2)cc1[R]</smiles>

$1 \mathrm{R}_{1}=\mathrm{R}_{2}=\mathrm{R}_{3}=\mathrm{R}_{4}=\mathrm{OCH}_{2} \mathrm{O}$

$2 \mathrm{R}_{1}=\mathrm{OMe} ; \mathrm{R}_{2}=\mathrm{OH} ; \mathrm{R}_{3}=\mathrm{R}_{4}=\mathrm{OCH}_{2} \mathrm{O}$

$3 \mathrm{R}_{1}=\mathrm{R}_{3}=\mathrm{OMe} ; \mathrm{R}_{2}=\mathrm{R}_{4}=\mathrm{OH}$<smiles>COc1ccc([C@H]2O[C@@H](c3ccc(OC)c(OC)c3)[C@H](C)[C@@H]2C)cc1OC</smiles>

4

Figure 1. Chemical structures of neolignans 1-4 isolated from S. cernuus

of 1 and 2 showed, respectively, singlets at $\delta 5.86(4 \mathrm{H})$ and 5.90 $(2 \mathrm{H})$ assigned to methylenedioxyl groups. In the case of compound 2, two additional singlets at $\delta 3.83$ and 5.50 were assigned to hydrogens of methoxyl and hydroxyl groups, respectively. An intense singlet at $\delta 3.80(6 \mathrm{H})$ was observed in the ${ }^{1} \mathrm{H}$ NMR spectrum of $\mathbf{3}$, which was attributed to hydrogens of two methoxyl groups linked to aromatic ring. In addition, the ${ }^{13} \mathrm{C}$ NMR spectra of 1-3 confirmed the occurrence of dibenzylbutane neolignans derivatives due to the presence of signals at $\delta 107-148$, attributed to aromatic carbons $\mathrm{C}-1$ to $\mathrm{C}-6$ and $\mathrm{C}-1$ 'to $\mathrm{C}-6$ ', and peaks of $\mathrm{C}_{3}$ unit at $\delta 41.1$ (C-7/C-7'), 37.5-39.2 (C-8/C-8'), and $\delta 13.9$ (C-9/C-9'). Finally, based on chemical shifts of C-7/C-7', C-8/C-8' and C-9/C-9' and comparison with data described in the literature, ${ }^{22,23}$ the isolated neolignans 1-3 displayed a threo configuration between methyl groups. LREIMS of $\mathbf{1 - 3}$ displayed peaks in the spectra that corresponded to molecular ions at $\mathrm{m} / \mathrm{z}, 326,328$ and 330 consistent, respectively, with molecular masses $\mathrm{C}_{20} \mathrm{H}_{22} \mathrm{O}_{4}, \mathrm{C}_{20} \mathrm{H}_{24} \mathrm{O}_{4}$ and $\mathrm{C}_{20} \mathrm{H}_{26} \mathrm{O}_{4}$. Finally, comparison of NMR and MS data with that reported in the literature identified threo-austrobailignan-5 (1), ${ }^{23-25}$ threo-austrobailignan-6 (2) ${ }^{26}$ and threo-dihydroguaiaretic acid (3). ${ }^{27}$ The ${ }^{1} \mathrm{H}$ NMR spectrum of compound $\mathbf{4}$ displayed signals of aromatic hydrogens at $\delta 6.85$ (br s) which were assigned to $\mathrm{H}-2 / \mathrm{H}-2^{\prime}$, $\mathrm{H}-5 / \mathrm{H}-5^{\prime}$ and $\mathrm{H}-6 / \mathrm{H}^{\prime} 6^{\prime}$. This peak associated to those at $\delta 5.45$ (d, $\left.J=5.3 \mathrm{~Hz}, \mathrm{H}-7 / \mathrm{H}^{\prime} 7^{\prime}\right)$ and $\delta 0.69(\mathrm{~d}, J=6.8 \mathrm{~Hz}$ ) suggested the occurrence of tetrahydrofuran neolignan containing a cis-trans-cis stereochemistry in the tetrahydrofuran ring. ${ }^{28}$ One intense singlet at $\delta 3.87(12 \mathrm{H})$ was assigned to four equivalent methoxyl groups at C-3/C-3'and C-4/C-4'. The ${ }^{13} \mathrm{C}$ NMR spectrum of $\mathbf{4}$ showed the peaks assigned to aromatic carbons $\mathrm{C}-1 / \mathrm{C}-1^{\prime}$ to $\mathrm{C}-6 / \mathrm{C}-6^{\prime}$ at range $\delta$ 148.6-109.6, to oximethine carbon $\left(\mathrm{C}-7 / \mathrm{C}^{\prime}\right)$ at $\delta 83.7$ and to methyl carbons (C-9/C-9') at $\delta 14.7$. Additionally, the presence of methoxyl groups was confirmed by the presence of an intense peak at $\delta$ 55.9. LRESIMS of $\mathbf{4}$ displayed a quasi-molecular ion peak at $\mathrm{m} / z 395[\mathrm{M}+\mathrm{Na}]^{+}$and $411[\mathrm{M}+\mathrm{K}]^{+}$consistent with molecular mass $\mathrm{C}_{22} \mathrm{H}_{28} \mathrm{O}_{5}$. Finally, comparison of the NMR data of $\mathbf{4}$ with those reported in the literature ${ }^{29}$ allowed the identification of saucernetin.

Based on the $\mathrm{IC}_{50}$ values (Table 1), compound $\mathbf{1}$ displayed reduced cytotoxic activity to all tested cells while the related neolignan 2 exhibited higher potential against HeLa cells with $\mathrm{IC}_{50}$ of $28.3 \pm 3.9 \mu \mathrm{g} \mathrm{mL}^{-1}\left(86 \pm 12 \mu \mathrm{mol} \mathrm{L} \mathrm{L}^{-1}\right)$, similar as observed to positive control cisplatin $\left(\mathrm{IC}_{50}=20.6 \pm 1.5 \mu \mathrm{g} \mathrm{mL} \mathrm{m}^{-1}\right.$

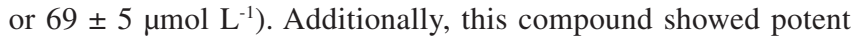
cytotoxicity against $\mathrm{B} 16 \mathrm{~F} 10$ cell $\left(\mathrm{IC}_{50}=32.8 \pm 2.1 \mu \mathrm{g} \mathrm{mL} \mathrm{m}^{-1}\right.$ or $\left.100 \pm 6 \mu \mathrm{mol} \mathrm{L}^{-1}\right)$, which was stronger than cisplatin $\left(\mathrm{IC}_{50}=53.1 \pm 4.2 \mu \mathrm{g} \mathrm{mL} \mathrm{m}^{-1}\right.$ or $\left.177 \pm 14 \mu \mathrm{mol} \mathrm{L}{ }^{-1}\right)$. Furthermore, compounds $\mathbf{2}$ and $\mathbf{3}$ exhibited cytotoxic activity against A2058 cells with $\mathrm{IC}_{50}$ of $44.3 \pm 4.2 \mu \mathrm{g} \mathrm{mL}^{-1}\left(135 \pm 13 \mu \mathrm{mol} \mathrm{L}{ }^{-1}\right)$ and $41.5 \pm 7.5 \mu \mathrm{g} \mathrm{mL} \mathrm{g}^{-1}(126 \pm 23 \mu \mathrm{mol} \mathrm{L}-1)$, respectively, similarly to cisplatin $\left(\mathrm{IC}_{50}=43.2 \pm 3.2 \mu \mathrm{g} \mathrm{mL}^{-1}\right.$ or $\left.144 \pm 11 \mu \mathrm{mol} \mathrm{L}-1\right)$. Both compounds were less cytotoxic against the non-tumorigenic cell line (T75), since the $\mathrm{IC}_{50}$ values remained higher in comparison with tumor cell lines with $\mathrm{IC}_{50}$ values of $53.2 \pm 3.6 \mu \mathrm{g} \mathrm{mL} \mathrm{m}^{-1}$ $\left(162 \pm 11 \mu \mathrm{mol} \mathrm{L} \mathrm{L}^{-1}\right)$ for compound 2 and $66.7 \pm 8.5 \mu \mathrm{g} \mathrm{mL} \mathrm{m}^{-1}$ $\left(202 \pm 26 \mu \mathrm{mol} \mathrm{L}^{-1}\right)$ for compound $\mathbf{3}$. Otherwise, compound 4 was inactive since calculated $\mathrm{IC}_{50}$ values were higher than $100 \mu \mathrm{g} \mathrm{mL}^{-1}$ (>300 $\mu \mathrm{mol} \mathrm{L}^{-1}$ ) to all tested cells. Due to the structural similarities between compounds $\mathbf{1 - 3}$, it is interesting to observe that the presence of methylenedioxyl group in both aromatic rings, as in the case of compound $\mathbf{1}$, cause a reduction in the cytotoxic potential. Otherwise, it was observed an increasing of activity to compounds $\mathbf{2}$ and $\mathbf{3}$ in which methoxyl and hydroxyl groups are linked directly in the aromatic ring. This effect could be justified, at least in part, to reduction of levels of reactive oxygen species caused by the presence of phenolic group, as observed to tetrahydrofuran neolignan $\mathbf{4}$ and related derivatives isolated from Nectandra leucantha (Lauraceae). ${ }^{30}$

Previous studies showed that related compounds erythroaustrobailignan-6 and meso-dihydroguaiaretic acid, isolated from S. chinensis, ${ }^{31}$ displayed cytotoxicity against HT-29 (human colon adenocarcinoma), MCF-7 (human breast adenocarcinoma) and HepG2 (human liver hepatoblastoma). Furthermore, compound 3 (threo-dihydroguaiaretic acid) was previously evaluated against HL-60 and HeLa cell lines with $\mathrm{IC}_{50}$ values of $25.7 \pm 0.9$ and $21.7 \pm 4.1 \mu \mathrm{mol} \mathrm{L}{ }^{-1}$, respectively. ${ }^{32}$ However, this is the first report describing the cytotoxic activity of compounds $\mathbf{1 - 3}$ as well as their selectivity to tumorigenic and non-tumorigenic cell lines. Based in the obtained results, further studies aiming determination of the mechanism of action of bioactive compounds $\mathbf{2}$ and $\mathbf{3}$ must be

Table 1. Cytotoxic effects of compounds 1-4 isolated from leaves of S. cernuus and positive control cisplatin against tumorigenic and non-tumorigenic cell lines

\begin{tabular}{lccccc}
\hline & \multicolumn{5}{c}{$\mathrm{IC}_{50} / \mu \mathrm{g} \mathrm{mL} \mathrm{m}^{-1}(\mu \mathrm{mol} \mathrm{L}-1)$} \\
\cline { 2 - 6 } & $\mathrm{B} 16 \mathrm{~F} 10$ & $\mathrm{~A} 2058$ & $\mathrm{HeLa}$ & $\mathrm{MCF}-7$ & $\mathrm{~T}$ \\
$\mathbf{1}$ & $97.5 \pm 9.4(299 \pm 29)$ & $>100(>300)$ & $90.9 \pm 11.4(279 \pm 35)$ & $>100(>300)$ & $>100(>300)$ \\
$\mathbf{3}$ & $32.8 \pm 2.1(100 \pm 6)$ & $44.3 \pm 4.2(135 \pm 13)$ & $28.3 \pm 3.9(86 \pm 12)$ & $46.3 \pm 1.9(141 \pm 6)$ & $53.2 \pm 3.6(162 \pm 11)$ \\
$\mathbf{4}$ & $52.6 \pm 6.6(159 \pm 20)$ & $41.5 \pm 7.5(126 \pm 23)$ & $45.5 \pm 12.7(138 \pm 38)$ & $36.3 \pm 3.5(110 \pm 11)$ & $66.7 \pm 8.5(202 \pm 26)$ \\
\hline Cisplatin & $>100(>300)$ & $>100(>300)$ & $>100(>300)$ & $>100(>300)$ & $>100(>300)$ \\
\hline
\end{tabular}

B16F10, murine melanoma; A2058, human melanoma; HeLa, human cervical carcinoma; MCF-7, breast adenocarcinoma tumorigenic cells and T75, human fibroblast non-tumorigenic cell. 
performed in order to eventually propose the use of these neolignans as antitumor agents.

\section{CONCLUSIONS}

In the present work, the leaves of $S$. cernuus were subjected to a microwave-assisted extraction (MAE) procedure using an ionic liquid aqueous solution (1-butyl-3-methylimidazolium bromide, $\mathrm{BMImBr}$ ). After partition with $n$-hexane a bioactive organic phase was obtained and was subjected to a bioactivity-guided procedure. This approach afforded three cytotoxic (1-3) and one inactive (4) neolignans. Isolated compounds were identified by analysis of the NMR and MS spectral data and comparison with those described in the literature. Compound $\mathbf{1}$ displayed reduced toxicity while $\mathbf{2}$ exhibited cytotoxic activity against HeLa cells similar as observed to positive control cisplatin. Similarly, compounds $\mathbf{2}$ and $\mathbf{3}$ exhibited cytotoxicity against A2058 cells. This study reports, at first time, the use of a simple and fast method employing a green solvent as 1-butyl3-methylimidazolium bromide (BMImBr) to S. cernuus species and the obtained results provide important data for the selection of bioactive neolignans with cytotoxic potential.

\section{EXPERIMENTAL SECTION}

\section{General experimental procedures}

Silica gel (Merck, 230-400 mesh) was used for the column chromatographic (CC) separation, while silica gel $60 \mathrm{PF}_{254}$ (Merck) was used for analytical thin-layer chromatography (TLC). ${ }^{1} \mathrm{H}$ and ${ }^{13} \mathrm{C}$ nuclear magnetic resonance (NMR) spectra were recorded at 300 and $75 \mathrm{MHz}$, respectively, in a Bruker Ultrashield 300 Avance III spectrometer. $\mathrm{CDCl}_{3}$ (Aldrich) was the solvent and the residual resonance peaks at $\delta_{\mathrm{H}} 7.26\left({ }^{1} \mathrm{H}\right)$ and $\delta_{\mathrm{C}} 77.2\left({ }^{13} \mathrm{C}\right)$ were used as internal standard. LRESIMS and LREIMS $(70 \mathrm{eV})$ spectra were recorded, respectively, using a Platform II-Micromass Spectrometer (quadrupole) and INCOS 50 Finnigan-Mat (quadrupole) mass spectrometers. Microwave assisted extraction (MAE) experiments were performed with a MAS-I microwave oven (2450 MHz, Sineo Microwave Chemistry Technology Company, Shanghai, China) with a maximum delivered power of $1000 \mathrm{~W}$. The temperature was monitored by an infrared probe inside the microwave oven.

\section{Plant material}

Plant material was obtained from a local producer of ornamental plants in the city of Suzano, São Paulo State. The botanical identification was made by Profs. Dr. Fátima O. de Souza Buturi and Dr. Oriana A. Fávero and the voucher specimen (E. A. Ferreira-001) was deposited at SPF Herbarium of the Institute of Biosciences of the University of São Paulo.

\section{Extraction and isolation}

1-butyl-3-methylimidazolium bromide (BMImBr) was prepared as previously described in the literature. ${ }^{21}$ Dried and powdered leaves $(5.0 \mathrm{~g})$ of $S$. cernuus were extracted by microwave-assisted extraction (MAE) with $20 \mathrm{~mL}$ of mixture containing $\mathrm{H}_{2} \mathrm{O}: \mathrm{BMImBr}$ $1: 1(\mathrm{v} / \mathrm{v})$ during $10 \mathrm{~min}$ at $60^{\circ} \mathrm{C}$. After this procedure, the solution was filtered, extracted using $n$-hexane $(3 \times 30 \mathrm{~mL})$ and dried over $\mathrm{Na}_{2} \mathrm{SO}_{4}$. After distillation of the solvent under reduced pressure, were obtained $215 \mathrm{mg}$ of $n$-hexane phase. Part of the this material $(200 \mathrm{mg}$ ) was fractionated over silica gel 60 column chromatography eluted with increasing amounts of EtOAc in $n$-hexane to afford five fractions (A-E), in which bioactivity was detected on fractions A (30 mg), C (10 mg) and D (33 mg). Fractions A and C were individually purified using silica gel 60 column chromatography eluted with hexane:EtOAc 9:1 to afford, respectively, compounds 1 (9.2 $\mathrm{mg})$ and $2(2.5 \mathrm{mg})$. Fraction D was subjected to silica gel column chromatography eluted with increasing amounts of EtOAc in $n$-hexane to give compounds $\mathbf{3}(5.1 \mathrm{mg})$ and $\mathbf{4}(2.6 \mathrm{mg})$.

Threo-austrobailignan-5 (1). Pale yellow oil. ${ }^{1} \mathrm{H}$ NMR $(\delta$, $\left.300 \mathrm{MHz}, \mathrm{CDCl}_{3}\right)$ : 6.56 (d, $J=1.5 \mathrm{~Hz}, \mathrm{H} 2 / \mathrm{H}^{\prime}$ ); 6.68 (d, $J=7.8 \mathrm{~Hz}$, H5/H5'); 6.50 (dd, $J=7.8$ and $1.5 \mathrm{~Hz}, \mathrm{H} 6 / \mathrm{H6}^{\prime}$ ); 2.31 (dd, $J=13.5$ and $\left.8.1 \mathrm{~Hz}, \mathrm{H} 7 \mathrm{a} / \mathrm{H}^{\prime} \mathrm{a}^{\prime}\right) ; 2.53\left(\mathrm{dd}, J=13.5\right.$ and $\left.6.6 \mathrm{~Hz}, \mathrm{H} 7 \mathrm{~b} / \mathrm{H}^{\prime} \mathrm{b}^{\prime}\right)$; 1.72 (m, H8/H8'); 0.79 (d, $\left.J=6.6 \mathrm{~Hz}, \mathrm{H}^{\prime} / \mathrm{H}^{\prime} 9^{\prime}\right) ; 5.85\left(\mathrm{~s}, \mathrm{OCH}_{2} \mathrm{O}\right)$. ${ }^{13} \mathrm{C} \mathrm{NMR}\left(\delta, 75 \mathrm{MHz}, \mathrm{CDCl}_{3}\right)$ : $147.5\left(\mathrm{C}^{3} / \mathrm{C}^{\prime}\right)$ ); 145.5 (C4/C4'); 135.4 (C1/C1'); 121.8 (C6/C6'); 109.7 (C2/C2'); 107.9 (C5/C5'); 100.7 $\left(\mathrm{OCH}_{2} \mathrm{O}\right) ; 41.2\left({\mathrm{C} 7 / \mathrm{C}^{\prime}}^{\prime}\right) ; 38.2$ (C8/C8'); 13.9 (C9/C9'). LREIMS

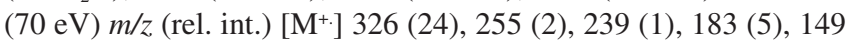
(6), 135 (100), 105 (10), 77 (18).

Threo-austrobailignan-6 (2). Pale yellow oil. ${ }^{1} \mathrm{H}-\mathrm{NMR}(\delta$, $\left.300 \mathrm{MHz}, \mathrm{CDCl}_{3}\right)$ : 6.61 (d, $J=1.5 \mathrm{~Hz}, \mathrm{H} 2 / \mathrm{H}_{2}$ ) $) ; 6.81$ (d, $J=7.8 \mathrm{~Hz}$, H5); 6.72 (d, $\left.J=7.8 \mathrm{~Hz}, \mathrm{H}^{\prime}\right)$; 6.56 (dd, $J=7.8$ and $\left.1.5 \mathrm{~Hz}, \mathrm{H} 6\right) ; 6.60$ (dd, $J=7.8$ and $\left.1.5 \mathrm{~Hz}, \mathrm{H6}^{\prime}\right) ; 2.54$ (dd, $J=13.5$ and $6.6 \mathrm{~Hz}, \mathrm{H} 7 \mathrm{a} /$ H7a'); 2.26 (ddd, $J=13.5$ and $8.1 \mathrm{~Hz}, \mathrm{H} 7 \mathrm{~b} / \mathrm{H}^{\prime} \mathrm{b}^{\prime}$ ); 1.75-1.66 (m, H8/ $\mathrm{H}^{\prime}$ ); 0.81 (d, $\left.J=6.3 \mathrm{~Hz}, \mathrm{H} 9 / \mathrm{H}^{\prime}{ }^{\prime}\right) ; 5.90$ (s, $\left.\mathrm{OCH}_{2} \mathrm{O}\right)$; 3.83 (s, OMe); $5.50(\mathrm{~s}, \mathrm{OH}) .{ }^{13} \mathrm{C} \mathrm{NMR}\left(\delta, 75 \mathrm{MHz}, \mathrm{CDCl}_{3}\right)$ : $147.4(\mathrm{C} 3) ; 146.3\left(\mathrm{C}^{\prime}\right)$; 145.4 (C4); 143.6 (C4'); 135.5 (C1); 133.5 (C1`); 121.7 (C6/C6'); 113.9 (C5'); 111.3 (C2'); 109.3 (C5); $107.4(\mathrm{C} 2) ; 100.7\left(\mathrm{OCH}_{2} \mathrm{O}\right)$; 55.8 (OMe); 39.2 (C7); 39.0 (C7'); 41.1 (C8 and $\mathrm{C}^{\prime}$ ); 13.9 (C9);

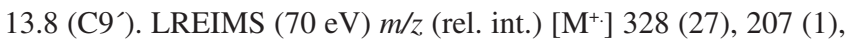
192 (2), 149 (1), 137 (100), 135 (67), 122 (13), 105 (10), 77 (18).

Threo-dihydroguaiaretic acid (3). White amorphous solid. ${ }^{1} \mathrm{H}$ NMR ( $\left.\delta, 300 \mathrm{MHz}, \mathrm{CDCl}_{3}\right): 6.51$ (d, $\left.J=1.5 \mathrm{~Hz}, \mathrm{H} 2 / \mathrm{H} 2^{\prime}\right) ; 6.79$ (d, $J=7.8 \mathrm{~Hz}, \mathrm{H} 5 / \mathrm{H}^{\prime}$ ); 6.58 (dd, $J=7.8$ and $1.5 \mathrm{~Hz}, \mathrm{H} 6 / \mathrm{H}^{\prime}$ ); 2.55 (dd, $J=13.5$ and $\left.6.6 \mathrm{~Hz}, \mathrm{H} 7 \mathrm{a} / \mathrm{H}^{\prime} \mathrm{a}^{\prime}\right) ; 2.30$ (dd, $J=13.5$ and $8.1 \mathrm{~Hz}$, H7b/H7b'); 1.73 (m, H8/H8'); 0.82 (d, J=6.7 Hz, H9/H9'); 3.80 (s, $\mathrm{OMe}) .{ }^{13} \mathrm{C} \mathrm{NMR}\left(\delta, 75 \mathrm{MHz}, \mathrm{CDCl}_{3}\right): 146.3\left(\mathrm{C} 3 / \mathrm{C}^{\prime}\right) ; 143.5(\mathrm{C} 4 /$ $\mathrm{C}^{\prime}$ ); 133.6 (C1/C1'); 113.8 (C5/C5'); 121.6 (C6/C6'); 111.3 (C2/ $\left.\mathrm{C}^{\prime}{ }^{\prime}\right) ; 55.8$ (OMe); 41.1 (C7/C7'); 37.5 (C8/C8'); 13.9 (C9/C9'). LREIMS (70 eV) m/z (rel. int.) [M+'] 330 (18), 207 (1), 192 (2), 151 (1), 137 (100), 122 (17), 94 (8), 77 (1).

Saucernetin (4): White amorphous solid. ${ }^{1} \mathrm{H}$ NMR $(\delta, 300 \mathrm{MHz}$, $\mathrm{CDCl}_{3}$ ): 6.85 (br s, H2/H2', H5/H5' and H6/H6'); 5.45 (d, $J=5.3 \mathrm{~Hz}, \mathrm{H} 7 / \mathrm{H}^{\prime}$ ); 3.87 (s, OMe), 2.27 (m, H8/H8'); 0.69 (d, $\left.J=6.8 \mathrm{~Hz}, \mathrm{H} 9 / \mathrm{H}^{\prime}\right) .{ }^{13} \mathrm{C} \mathrm{NMR}\left(\delta, 75 \mathrm{MHz}, \mathrm{CDCl}_{3}\right): 148.7(\mathrm{C} 3 /$ $\left.\mathrm{C}^{\prime}\right) ; 147.9$ (C4/C4'); 133.9 (C1/C1' $) ; 118.5$ (C5/C5'); 110.8 (C2/ C2'); 109.6 (C6/C6'); 83.7 (C7/C7'); 55.9 (OMe); 44.0 (C8/C8'); 14.7 (C9/C9'). LRESIMS (positive mode) $\mathrm{m} / z 395[\mathrm{M}+\mathrm{Na}]^{+}$and $411[\mathrm{M}+\mathrm{K}]^{+}$.

\section{Cell culture}

The following tumorigenic cell lines were used: B16F10 murine melanoma, A2058 - human melanoma, HeLa - human cervical carcinoma, MCF-7 - human breast adenocarcinoma) and non-tumorigenic cell (T75 - human fibroblast). Tumor cells were cultured at $37{ }^{\circ} \mathrm{C}$ in a humid atmosphere containing $5 \% \mathrm{CO}_{2}$ using RPMI 1640 medium (Invitrogen, Carlsbad, CA). The T75 cell line was cultured in DMEM medium (Invitrogen, Carlsbad, CA) supplemented with $10 \mathrm{mmol} \mathrm{L}^{-1}$ 2-hydroxyethylpiperazine-N2 ethanesulfonic acid (Hepes) (Sigma, St. Louis, MO), $24 \mathrm{mmol} \mathrm{L}^{-1}$ sodium bicarbonate 
(Sigma), $40 \mathrm{mg} \mathrm{mL}^{-1}$ gentamicide (Schering-Plow, São Paulo), $\mathrm{pH}$ 7.2 and $10 \%$ fetal bovine serum (FBS - Invitrogen).

\section{Cell viability assay}

For the cytotoxicity assays, $1 \times 10^{4}$ viable cells were incubated in 96 wells plate in $100 \mu \mathrm{L}$ of complete media. After $8 \mathrm{~h}$ of inoculation, the studied cells were treated with isolated compounds 1-4 from S. cernuum in concentrations of $100,75,50,25$ and $12.5 \mu \mathrm{g} \mathrm{mL}^{-1}$, or fresh medium for the control cells. After $24 \mathrm{~h}, 10 \mu \mathrm{L}$ of MTT solution ( $5 \mathrm{mg} \mathrm{mL}^{-1}$ ) was added to each well, and the plate was incubated for $3 \mathrm{~h}$ at $37{ }^{\circ} \mathrm{C}$. Thus, $100 \mu \mathrm{L}$ of a $10 \% \mathrm{SDS} / 0.01 \mathrm{M} \mathrm{HCl}$ solution was added and incubated for $4 \mathrm{~h}$ at $37^{\circ} \mathrm{C}$. Readings of the absorbance were performed at $570 \mathrm{~nm}$ with a reference filter at $\lambda=650 \mathrm{~nm}$ using a plate reader (SpectraMax®-M2e, Molecular Devices, Sunnyvale, CA). Cell viability was expressed as percentage values comparing with viable cells at the negative control treatments. ${ }^{33,34}$ All experiments were performed in triplicates.

\section{ACKNOWLEDGEMENTS}

The authors thank FAPESP(2015/11936-2) and MACKPESQUISA (151024) for financial support for development of this work. J. R. B. and J. H. G. L. thanks, respectively, CAPES and CNPq for fellowships.

\section{REFERENCES}

1. Grímsson, F.; Grimm, G. W.; Zetter, R.; Peer J. 2017, 5:e3434.

2. Zhuang, T.; Li, F.; Huang, L.-R.; Liang, J.-Y.; Qu, W.; Chem. Biodiversity 2015, 12, 194.

3. Zhuang, T.; Xu, B.; Huang, L.; Chen, X.; Liang, J.; Qu, W.; J. Chin. Pharm. Univ. 2014, 45, 410.

4. Li, C.; Li, N.; Yue, J.; Song, Q.; Fan, Q.; Nat. Prod. Res. 2017, 31, 1598.

5. Lu, Y.; Son, J.-K.; Chang, H. W.; Biomol. Ther. 2012, 20, 526.

6. Gao, X.; He, J.; Wu, X. -D.; Peng, L.-Y.; Dong, L. -B.; Deng, X.; Li, Y.; Cheng, X.; Zhao, Q.-S.; Planta Med. 2013, 79, 1720.

7. Tsai, W.-J.; Shen, C.-C.; Tsai, T.; Lin, L.-C.; J. Nat. Prod. 2014, 77, 125.

8. Qu, W.; Xue, J.; Wu, F. H.; Liang, J. Y.; Chem. Nat. Compd. 2014, 50, 814.

9. Cui, H.; Xu, B.; Wu, T.; Xu, J.; Yuan, Y.; Gu, Q. J. Nat. Prod. 2014, 77, 100.

10. Li, N.; Tuo, Z.-D.; Qi, S.-Z.; Xing, S.-S.; Lee, H.-S.; Chen, J.-G.; Cui, L.; Fitoterapia 2015, 101, 46.

11. Lee, A. K.; Sung, S. H.; Kim, Y. C.; Kim, S. G.; Br. J. Pharmacol. 2003, $139,11$.
12. Hodges, T.; Hossain, C. H.; Kim, Y.-P.; Zhou, Y.-D.; Nagle, D. G.; J. Nat. Prod. 2004, 67, 767.

13. Sung, S. H.; Kim,Y. C.; J. Nat. Prod. 2000, 63, 1019.

14. Kubanek, J.; Fenical, W.; Hay, M. E.; Brown, P. J.; Lindquist, N.; Phytochemistry 2000, 54, 281.

15. Yoo, H.-J.; Kang, H.-J.; Jung, H.J.; Kim, K.; Lim, C.-J.; Park, E.-H.; J. Ethnopharmacol. 2008, 120, 282.

16. Hodges, T. W.; Hossain, C. F.; Kim, Y.-P.; Zhou, Y.-D.; Nagle, D. G.; J. Nat. Prod. 2004, 67, 767.

17. Lee, Y. J.; Kim, J.; Yi, J.-M.; Oh, S.-M.; Kim, N. S.; Kim, H.; Oh, D.-S.; Bang, O.-S.; Lee, J.; Biol. Pharm. Bull. 2012, 35, 1361.

18. Hossain, C. F.; Kim, Y.-P.; Baerson, S. R.; Zhang, L.; Bruick, R. K.; Mohammed, K. A.; Agarwal, A. K.; Nagle, D. G.; Zhou,Y.-D.; Biochem. Biophys. Res. Commun. 2005, 333, 1026.

19. Chin, Y.-W.; Cai, X.-F.; Ahn, K.-S.; Lee, H.-K.; Oh, S.-R.; Bull. Korean Chem. Soc. 2010, 31, 2088

20. Daí, Y.; Spronsen, J. V.; Witkamp, G.-J.; Veepoorte, R.; Choi, Y. H.; J. Nat. Prod. 2013, 76, 2162.

21. Morais, T. R.; Coutinho, A. P.R.; Camilo, F. F.; Martins, T. S.; Sartorelli, P.; Massaoka, M. H.; Figueiredo, C. R.; Lago, J. H. G.; J. Braz. Chem. Soc. 2017, 28, 492.

22. Martinez, J. C.; Yoshida, M.; Gottlieb, O. R.; Phytochemistry 1990, 29, 2655.

23. Bandera Herath, H. M. T.; Anoma Priyadarsini, A. M.; Phytochemistry 1997, 44, 699

24. Rao, K. V.; Oruganty, R. S.; J. Liq. Chromatogr. Relat. Technol. 1997, 20, 3121.

25. Rao, K. V.; Alvarez, F. M.; J. Nat. Prod. 1982, 45, 393.

26. Murphy, S. T.; Ritchie, E.; Taylor, W.C.; Aust. J. Chem. 1975, $28,81$.

27. Alvarez, E. A.; Cuca, L. E. S.; Martinez, J. C. V.; Rev. Colomb. Quím. 1985, 14,31 .

28. Rao, K.V.; Alvares, F.M.; J. Nat. Prod. 1982, 45, 393.

29. Rao, K.V.; Oruganty, R. S.; J. Liq. Chromatogr. Relat. Technol. 1997, 20,3121.

30. Ponci, V.; Figueiredo, C. R.; Massaoka, M. H.; Farias, C. F.; Matsuo, A. L.; Sartorelli, P. S.; Lago, J. H. G.; Molecules 2015, 20, 12757.

31. Lee,Y.-K.; Seo, C.-S.; Lee, C.-S; Lee, K.-S.; Kang, S.-J.; Jahng, Y.; Chang, H. W.; Son, J.-K.; Arch. Pharm. Res. 2009, 32, 10.

32. Wukirsari, T.; Nishiwaki, H.; Nishi, K.; Sugahara, T.; Akiyama, K.; Kishida, T.; Yamauchi, S. J. Agric. Food Chem. 2014, 62, 5305.

33. Conserva, G. A. A.; Azevedo, R. A.; Figueiredo, C. R.; Sartorelli, P.; Soares, M. G.; Lago, J. H. G.; Planta Med. 2017, 83, 1289.

34. Sousa, F. S.; Greco, S. S.; Girola, N.; Azevedo, R. A.; Figueiredo, C. R.; Lago, J. H. G.; Phytochemistry 2017, 140, 108. 